medRxiv preprint doi: https://doi.org/10.1101/2021.06.29.21259431; this version posted July 3, 2021. The copyright holder for this preprint (which was not certified by peer review) is the author/funder, who has granted medRxiv a license to display the preprint in perpetuity. It is made available under a CC-BY-NC-ND 4.0 International license .

\title{
The development and usability testing of digital knowledge translation tools for parents of children with acute otitis media
}

\author{
Anne Le, MPH ${ }^{1}$ \\ Lisa Hartling, $\mathrm{PhD}^{2}$ \\ Shannon D. Scott, PhD, $\mathrm{RN}^{1}$
}

${ }^{1}$ Faculty of Nursing, University of Alberta, Edmonton, AB, Canada

${ }^{2}$ Department of Pediatrics, University of Alberta, Edmonton, AB, Canada

\begin{abstract}
Acute otitis media (AOM) is the most common bacterial ear infection affecting up to $80 \%$ of children before the age of three. Despite the common occurrence of the illness and the wide range of material available at clinics and online, parents are not always aware of these resources and they are often difficult to understand. We worked with parents to develop and assess the usability of a whiteboard animation video and interactive infographic for AOM in children. Parents rated the tools highly across all usability items, suggesting that creative tools developed using multimethod development processes can be useful, relevant, understandable, and will be used by the intended audience.
\end{abstract}

Following the completion of the English-language products, our team culturally adapted the tools for the Pakistan context and evaluated the usability of these adapted tools. During usability testing, parents indicated that they felt the tools were useful, demonstrating that culturally adapted version of knowledge translations tools are effective in ensuring that parents could understand complex health information. 
medRxiv preprint doi: https://doi.org/10.1101/2021.06.29.21259431; this version posted July 3, 2021. The copyright holder for this preprint (which was not certified by peer review) is the author/funder, who has granted medRxiv a license to display the preprint in perpetuity. It is made available under a CC-BY-NC-ND 4.0 International license .

\section{Author Contributions}

This study was conducted under the supervision of Drs. Shannon D. Scott (SDS) and Lisa Hartling (LH), Pls for translation Evidence in Child Health to enhance Outcomes $(\mathrm{ECHO})$ Research and the Alberta Research Centre for Health Evidence, respectively. Both Pls designed the research study and obtained research funding through Translating Emergency Knowledge for Kids (TREKK) Networks of Centres of Excellence of Canada (NCE).

SS designed and supervised all aspects of tool development and evaluation.

LH co-designed and was involved in all aspects of tools development and evaluation.

Tony An developed the infographic.

Salima Meherali conducted and analyzed qualitative interviews with parents.

Anne Le (AL), Alyson Campbell, Chentel Cunningham and Tabatha Plesuk conducted usability testing.

$\mathrm{AL}$ analyzed usability data.

All authors contributed to the writing of this technical report and provided substantial feedback.

This work was funded by:

Networks of Centres of Excellence:

- Klassen, T., Hartling, L., Jabbour, M., Johnson, D., \& Scott, S.D. (2015). Translating emergency knowledge for kids (TREKK). Networks of Centres of Excellence of Canada Knowledge Mobilization Renewal $(\$ 1,200,000)$. January 2016 - December 2019.

Women and Children's Health Research Institute (WCHRI):

- Scott, S.D \& Hartling L. (2016). Translating Emergency Knowledge for Kids renewal. Women and Children's Health Research Institute (matched dollars, \$150,000). April 2016 - December 2019.

This report should be cited as:

Le, A., Hartling, L., Scott, S.D. (2021). The development and usability testing of digital knowledge translation tools for parents of children with acute otitis media. Technical Report. ECHO Research, University of Alberta.

Available at: http://www.echokt.ca/research/technical-reports/ 


\section{Table of Contents}

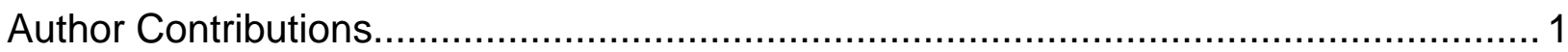

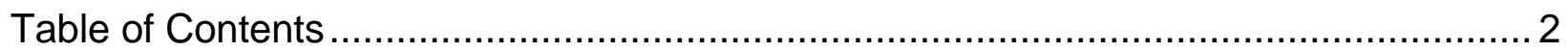

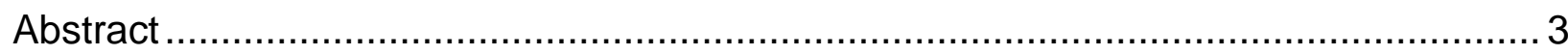

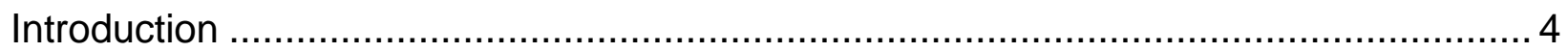

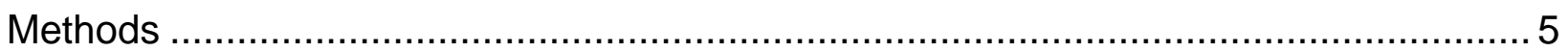

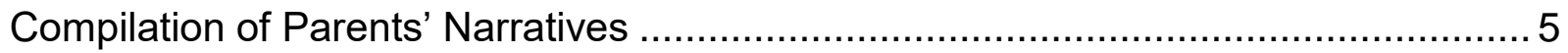

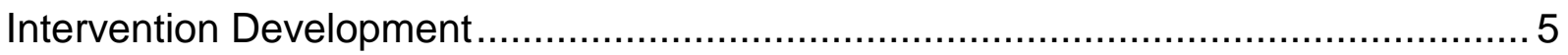

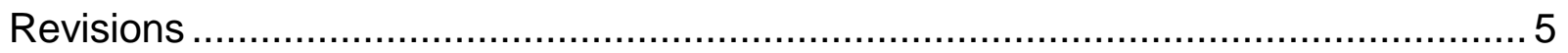

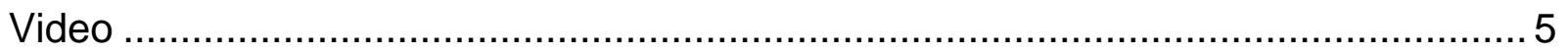

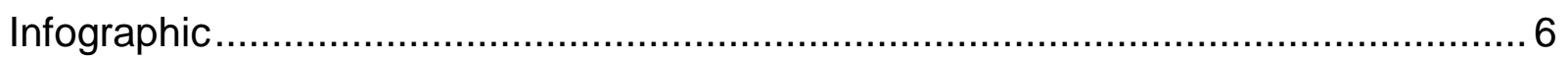

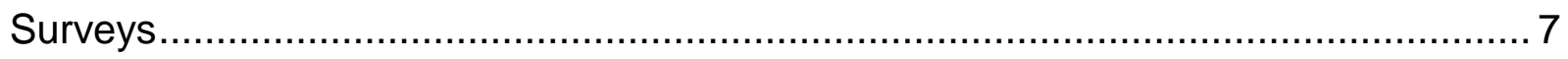

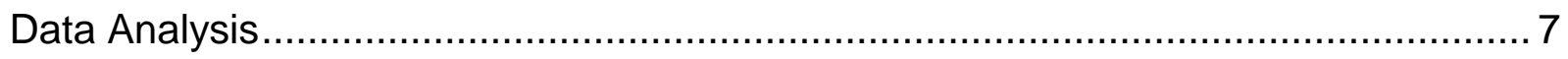

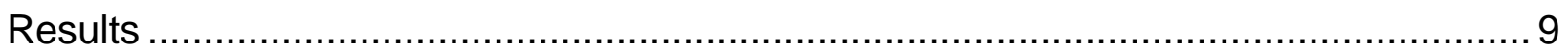

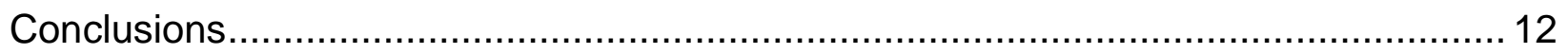

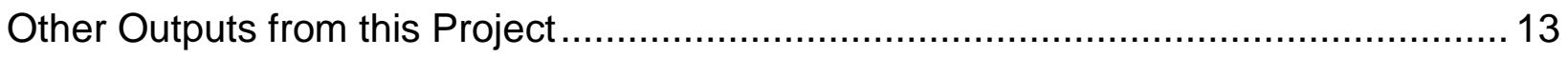

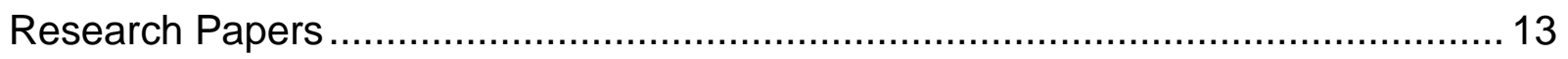

Outputs from the Pakistan AOM Project..................................................... 14

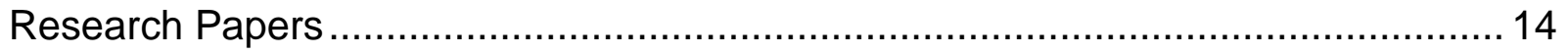

Presentations \& Research Conferences .............................................. 14

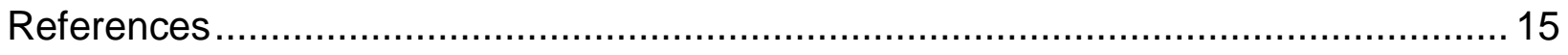

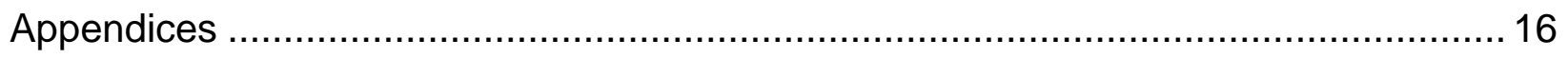

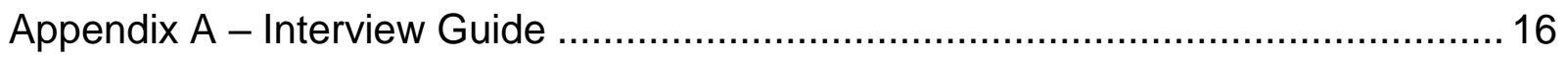

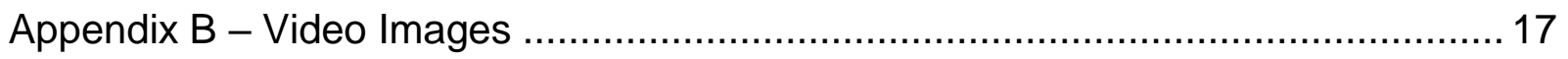

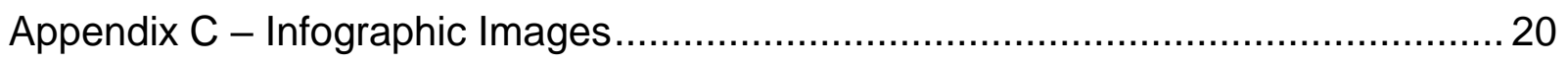

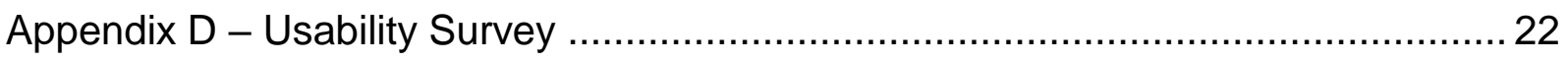

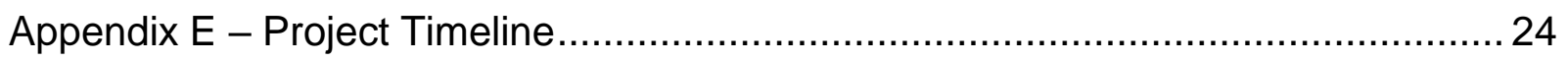


medRxiv preprint doi: https://doi.org/10.1101/2021.06.29.21259431; this version posted July 3, 2021. The copyright holder for this preprint (which was not certified by peer review) is the author/funder, who has granted medRxiv a license to display the preprint in perpetuity.

\begin{abstract}
Acute otitis media (AOM) is the most common bacterial ear infection affecting up to $80 \%$ of children before the age of three. Despite the common occurrence of the illness and the wide range of material available at clinics and online, parents are not always aware of these resources and they are often difficult to understand. We worked with parents to develop and assess the usability of a whiteboard animation video and interactive infographic for AOM in children. Parents rated the tools highly across all usability items, suggesting that creative tools developed using multi-method development processes can be useful, relevant, understandable, and will be used by the intended audience.

Following the completion of the English-language products, our team culturally adapted the tools for the Pakistan context and evaluated the usability of these adapted tools. During usability testing, parents indicated that they felt the tools were useful, demonstrating that culturally adapted version of knowledge translations tools are effective in ensuring that parents could understand complex health information.
\end{abstract}


medRxiv preprint doi: https://doi.org/10.1101/2021.06.29.21259431; this version posted July 3, 2021. The copyright holder for this preprint (which was not certified by peer review) is the author/funder, who has granted medRxiv a license to display the preprint in perpetuity.

\section{Introduction}

Acute otitis media $(\mathrm{AOM})$ is a common infection of the middle ear that affects approximately $80 \%$ of children before the age of three. Caused by viruses, such as the respiratory syncytial virus (RSV), or bacteria, such as Streptococcus pneumoniae, symptoms of AOM are non-specific and can include irritability, ear pain, and fever [1-3]. Uncertainty about the cause and symptoms of AOM often results in difficulty with athome management, diagnosis, and treatment. Furthermore, significant discrepancies are found in practice, with some professionals treating with antibiotics, while others allowing infections to resolve spontaneously [4]. The ambiguity surrounding the diagnoses and treatment of AOM in children have been found to be associated with parental distress. Studies have revealed that parents have limited and inaccurate knowledge about AOM, suggesting that more effective information sources and mediums are required to educate parents $[5,6]$.

Storytelling is one of the oldest methods of communication that spans across all cultures and generations [7]. Previous studies have found that narratives have potential to convey complex health information from providers to patients and have been associated with increased patient health outcomes [8,9].

As co-directors of Translating Emergency Knowledge for Kids (TREKK), our research programs have developed and evaluated arts-based KT tools, demonstrating their use as effective sources of consumer-friendly, evidence-based information for parents. Combining parental narratives, results from systematic literature reviews, and best practice guidelines, we have developed an innovative method to equip parents with information and strategies to manage common childhood conditions (e.g., gastroenteritis, chronic pain, and croup).

The purpose of this study was to work with parents to develop and assess the usability of a whiteboard animation video and interactive infographic for AOM in children. 
medRxiv preprint doi: https://doi.org/10.1101/2021.06.29.21259431; this version posted July 3, 2021. The copyright holder for this preprint (which was not certified by peer review) is the author/funder, who has granted medRxiv a license to display the preprint in perpetuity. It is made available under a CC-BY-NC-ND 4.0 International license .

\section{Methods}

This multi-method study employed patient engagement to develop, refine, and evaluate a whiteboard animation video and interactive infographic for pediatric acute otitis media. Research ethics approval was obtained from the University of Alberta Health Research Ethics Board (Edmonton, AB) [Pro00062904], Izaak Walton Killam (IWK) Research Ethics Board (Halifax, NS), and University of Saskatchewan Research Ethics Board (Saskatoon, SK). Operational approvals were obtained from individual emergency departments to conduct usability testing.

\section{Compilation of Parents' Narratives}

Parental narratives were informed through 16 semi-structured qualitative interviews (Appendix A) and a systematic review. Parents of children who presented to the Stollery Children's Hospital (Edmonton, Canada) with AOM were invited to participate in interviews conducted by a project coordinator trained in qualitative methodology. Parents were asked about their experiences with pediatric AOM. Concurrently, a systematic review was conducted to synthesize current evidence about experiences and information needs of parents and caregivers managing acute otitis media. Results from the systematic review and qualitative interviews are published elsewhere [5].

\section{Intervention Development}

Information gathered from the systematic review and interviews were used to develop the video script and infographic skeleton. Information from the TRanslating Emergency Knowledge for Kids (TREKK) Bottom Line Recommendations (BLR) for acute otitis media was included in the script and skeleton, which were then shared with a creative team to develop the e-tool prototypes [10]. Information pertinent to management of AOM were embedded within the storyline of the video, which depicted a couple struggling to manage their child's ear pain (Appendix B). Likewise, information on symptoms, treatment options, and when to seek emergency care was included in the infographic (Appendix C).

\section{Revisions}

Iterative processes were used to develop the AOM video and infographic. Different stakeholder groups, including parents, health care professionals (HCPs), researchers, and the study team participated in several rounds of revisions. HCPs were asked to comment on the quality and accuracy of information and evidence, length of the tool, aesthetics, usefulness, and perceived value. Parents from our Pediatric Parent Advisory Group (P-PAG) were asked to provide feedback on the length, stylistic elements, and highlight areas not addressed in the tools. The P-PAG meets once a month and are asked to participate in tool development several times a year [11]. Likewise, our research team also holds weekly meetings to discuss the development of our tools.

\section{Video}

Over the course of 18-months, researchers worked with parents, HCPs, and the creative team to refine the tool for usability testing. Six versions of the video were developed before the AOM video was deemed ready for usability testing. The usability 
medRxiv preprint doi: https://doi.org/10.1101/2021.06.29.21259431; this version posted July 3, 2021. The copyright holder for this preprint (which was not certified by peer review) is the author/funder, who has granted medRxiv a license to display the preprint in perpetuity. It is made available under a CC-BY-NC-ND 4.0 International license .

testing video was 3 minutes and 5 seconds in length and featured a family of three whose child presents with symptoms of AOM. The storyline starts with a family (father, mother, child) at home preparing for bed when Sam develops a slight fever and ear pain. The mom, serving as the narrator, describes the parents' concern for their child. The parents then take the child to their family physician, resulting in an AOM diagnosis. The mom highlights information about AOM, as provided by their doctor, including a description of the condition and symptoms, what medications can be given, how to manage the condition at home, and when to seek healthcare and/or emergency care. Equipped with this information, the parents then decide to manage Sam at home. Unfortunately, their child's symptoms worsen the next day, prompting a visit to the ED, where they are prescribed antibiotics. The video further reiterates the course of actions that parents should take when their child has symptoms of AOM. As the narration plays, images and graphics appear on screen to further highlight the information being provided. The family doctor also prescribes antibiotics and explains that they should only be used if symptoms become worse (i.e., persisting pain and/or fluid coming from the child's ear). The parents then go home and Sam's AOM resolves shortly after. The characters were designed to be realistic, while certain features, such as sex, age, and race were kept ambiguous. The style of the video was whiteboard animation, which is characterized by having a hand "draw" and "write" in images and texts that appear across the screen.

The video was later entered into the Canadian Institutes of Health Research (CIHR) Institute of Human Development, Child and Youth Health (IHDCYH) 2019 Talks Video Competition and received special commendations.

\section{Infographic}

The AOM interactive infographic used a style that had been previously developed and tested for our pediatric procedural pain interactive infographic. This style which is unique to our tools underwent dozens of different iterations and took two years to develop. In order to ensure that our tools were consistent across all conditions, we used the same style, design elements, animations, and characters across all conditions in our suite of interactive infographic tools.

Our interactive infographic tools are developed to be similar to a webpage, such that they allow users to scroll through the information and explore at their own pace. Unlike videos or e-Books, such tools give parents the control to view what they need based on their needs. Information provided in our AOM interactive infographic was similar to information provided in our AOM video and consisted of seven different panels. These included: What is Acute Otitis Media?, Common Signs of AOM, Here's What You Can Do, What You Can Do At Home, Antibiotics, Additional Resources, and Contact Us. Our KT Tool Development Cycle can be viewed in Figure 1. 
medRxiv preprint doi: https://doi.org/10.1101/2021.06.29.21259431; this version posted July 3, 2021. The copyright holder for this preprint (which was not certified by peer review) is the author/funder, who has granted medRxiv a license to display the preprint in perpetuity. It is made available under a CC-BY-NC-ND 4.0 International license .

Figure 1. ARCHE-ECHO KT Tool Development Cycle

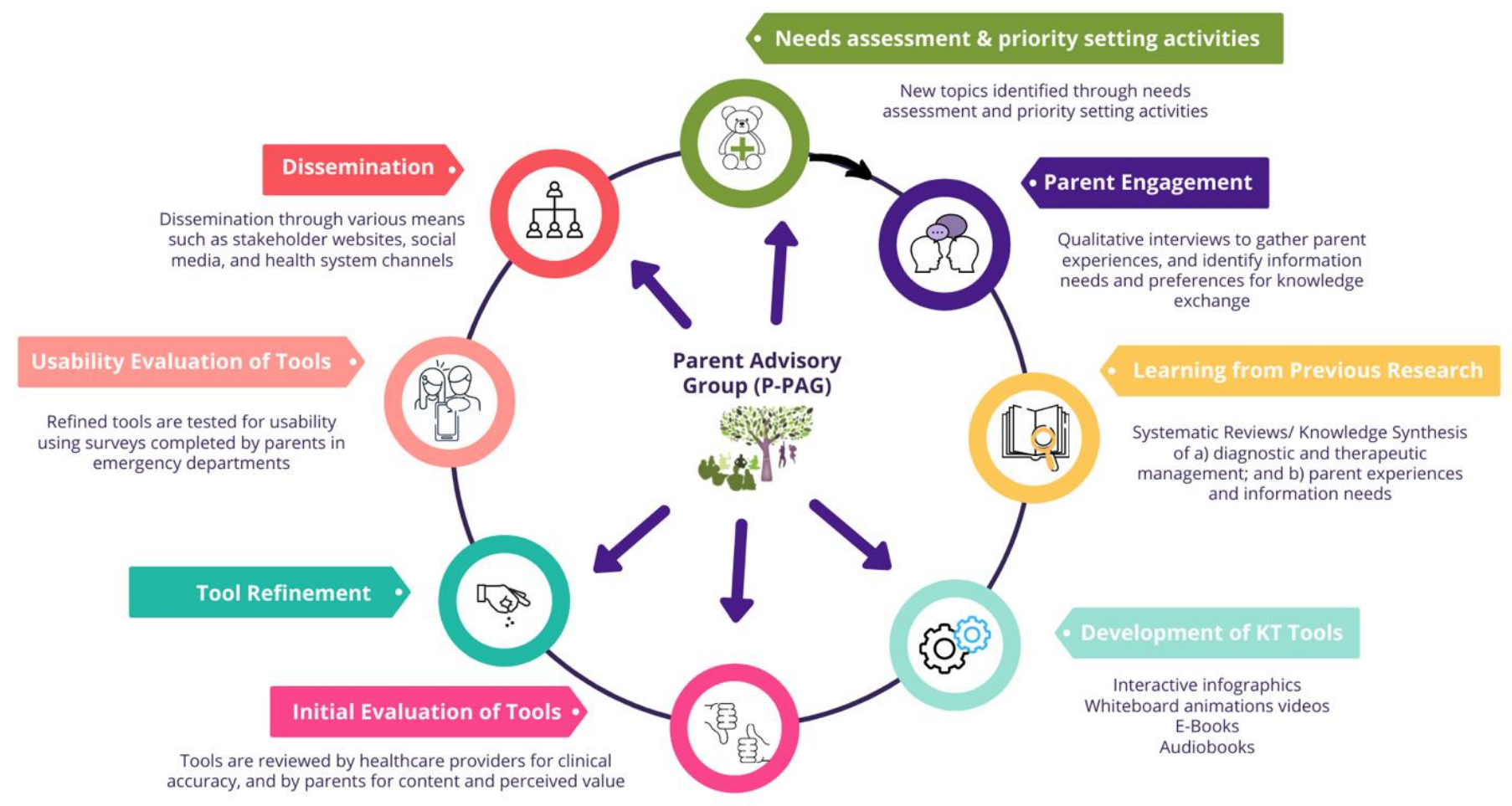

\section{Surveys}

Parents were recruited to participate in an electronic, usability survey (Appendix D) in rural and urban ED waiting rooms in Alberta, Saskatchewan, and Nova Scotia. These included the Cobequid Community Health Centre, Hants Community Hospital, and Colchester Community Health Centre in Nova Scotia, the Royal University Hospital in Saskatchewan, and Leduc Community Hospital in Alberta. Surveys were informed by a systematic review of over 180 usability evaluations and comprised of 9, 5-point Likert items assessing: 1) usefulness, 2) aesthetics, 3) length, 4) relevance, and 5) future use [12]. Parents were also asked to provide their positive and negative opinions of the tool via two free text boxes. Members of the study team approached parents in the ED to determine interest and study eligibility. Study team members were available in the ED to provide technical assistance and answer questions as parents were completing the surveys.

\section{Data Analysis}

Data were cleaned and analyzed using SPSS v.24. Descriptive statistics and measures of central tendency were generated for demographic questions. Likert answers were given a corresponding numerical score, from 5 to 1 , with 5 being "Strongly Agree" and 1 being "Strongly Disagree" [13-14]. T-tests were conducted to determine whether there were any significant differences between the mean scores for both tools. Open-ended 
medRxiv preprint doi: https://doi.org/10.1101/2021.06.29.21259431; this version posted July 3, 2021. The copyright holder for this preprint (which was not certified by peer review) is the author/funder, who has granted medRxiv a license to display the preprint in perpetuity. It is made available under a CC-BY-NC-ND 4.0 International license .

survey data were analyzed thematically. A summary of the results was then shared with the creative team to inform the development of the final versions of the tools. 
medRxiv preprint doi: https://doi.org/10.1101/2021.06.29.21259431; this version posted July 3, 2021. The copyright holder for this preprint (which was not certified by peer review) is the author/funder, who has granted medRxiv a license to display the preprint in perpetuity.

\section{Results}

58 parents participated in the study. Of those, 28 reviewed the whiteboard animation video, while 30 viewed the interactive infographic. Table 1 provides demographics of the sample.

Table 1. Demographic characteristics of parents who assessed the usability of the whiteboard animation video and infographic $(\mathrm{N}=58)$

\begin{tabular}{|l|c|}
\hline Characteristic & $\mathbf{n ~ ( \% )}$ \\
\hline Sex & $42(72.4)$ \\
Memale & $16(27.6)$ \\
\hline Age & \\
20-29 years & $7(12.1)$ \\
$30-39$ years & $20(34.5)$ \\
$40-49$ years & $24(41.4)$ \\
$50-59$ years & $6(10.3)$ \\
60 years and older & $1(1.7)$ \\
\hline Marital Status & \\
Married/Partnered & $48(82.8)$ \\
Single/Separated/Divorced/Widowed & $10(17.2)$ \\
\hline Education & \\
Some high school & $2(3.4)$ \\
High school diploma & $12(20.7)$ \\
Some post-secondary & $7(12.1)$ \\
Post-secondary certificate/diploma & $17(29.3)$ \\
Post-secondary degree & $15(25.9)$ \\
Graduate degree & $4(6.9)$ \\
\hline Household Income & \\
Less than $\$ 25,000$ & $3(5.2)$ \\
\$25,000-\$49,000 & $14(24.1)$ \\
\$50,000-\$74,000 & $12(20.7)$ \\
\$75,000-\$99,000 & $12(20.7)$ \\
\$100,000-\$149,000 & $8(13.8)$ \\
\$150,000 and over & $6(10.3)$ \\
Prefer not to answer & $3(5.2)$ \\
\hline Number of Children in the Family & $12(20.7)$ \\
1 & $19(32.8)$ \\
2 & $19(32.8)$ \\
3 & $3(5.2)$ \\
4 & $5(8.5)$ \\
$5+$ & \\
\hline
\end{tabular}


medRxiv preprint doi: https://doi.org/10.1101/2021.06.29.21259431; this version posted July 3, 2021. The copyright holder for this preprint (which was not certified by peer review) is the author/funder, who has granted medRxiv a license to display the preprint in perpetuity. It is made available under a CC-BY-NC-ND 4.0 International license .

In general, parents rated the AOM whiteboard animation video positively, resulting in mean scores of at least 4.10 out of 5.00 on all questions. All parents strongly agreed or agreed that the tool was simple to use (4.53) and that it could be used without written instructions or help (4.59). Likewise, parents felt that the length of the video was appropriate (4.43) and that the tool was aesthetically pleasing (4.50). Parents gave high scores when asked if they found the tool useful (4.39) and if the tool was relevant to them as parents (4.41). When asked about potential future usage of the tool, scores were 4.14 for both "I would use it in the future" and "it will help me make decisions about my child's health". Finally, when asked if parents would recommend the tool to a friend, parents gave a score of 4.25 .

Likewise, parents liked the interactive infographic, providing mean scores of 4.20 out of 5.00 on all questions. The highest score was given when we asked parents whether the tool was simple to use (4.63) while the lowest score was given for "it is useful" (4.20). Means were all 4.37 for relevancy, length, and aesthetics. Similarly, parents gave identical scores for "it helps me make decisions about my child's health" and "I would recommend it to a friend" (4.40). Finally, scores for future use and using the tool without additional help were 4.33 and 4.47 , respectively. When comparing the two tools, only future use scores were significantly different $(p<0.05)$. Table 3 provides a breakdown of the means in usability items for each tool.

Table 2. Means (SD) of participant responses to the usability survey

\begin{tabular}{|l|c|c|}
\hline \multicolumn{1}{|c|}{ Usability Measures } & AOM Video & AOM Infographic \\
\hline It is useful. & $4.39(0.63)$ & $4.20(1.06)$ \\
\hline $\begin{array}{l}\text { It provides information that is } \\
\text { relevant to me as a parent. }\end{array}$ & $4.41(0.69)$ & $4.37(0.63)$ \\
\hline It is simple to use. & $4.54(0.51)$ & $4.63(0.56)$ \\
\hline $\begin{array}{l}\text { I can use it without written } \\
\text { instructions or additional } \\
\text { help. }\end{array}$ & $4.59(0.50)$ & $4.47(0.51)$ \\
\hline Its length is appropriate. & $4.43(0.50)$ & $4.37(0.61)$ \\
\hline $\begin{array}{l}\text { It is aesthetically pleasing } \\
\text { (i.e. images, colours, etc.). }\end{array}$ & $4.5(0.51)$ & $4.37(0.67)$ \\
\hline $\begin{array}{l}\text { It helps me make decisions } \\
\text { about my child's health. }\end{array}$ & $4.14(0.76)$ & $4.40(0.62)$ \\
\hline I would use it in the future. & $4.14(0.59)$ & $4.33(0.71)^{*}$ \\
\hline $\begin{array}{l}\text { I would recommend it to a } \\
\text { friend. }\end{array}$ & $4.25(0.59)$ & $4.40(0.67)$ \\
\hline
\end{tabular}

${ }^{*} p<0.05$.

In the open text boxes, parents described the AOM video as "very helpful", "clear", and "easy to follow". One parent wrote, "I wish more parents could view this, as ear infections seem to be what takes a lot of kids to the doctor unnecessarily!" while another discussed the tool as a potential learning tool for older children, "Voice is clear, easy to understand, provided information I did not know. I found the tool very useful and would 
medRxiv preprint doi: https://doi.org/10.1101/2021.06.29.21259431; this version posted July 3, 2021. The copyright holder for this preprint (which was not certified by peer review) is the author/funder, who has granted medRxiv a license to display the preprint in perpetuity. It is made available under a CC-BY-NC-ND 4.0 International license.

help the older children understand what their diagnosis is and would possibly help them feel better to know what is going on inside them".

Parents described the AOM infographic as "useful", "clear", and felt that it provided "quick and easy access to information". Parents also stated that the infographic was appealing to look at while providing helpful information. Due to the positive scores and feedback from usability testing with parents, very few changes were made to the AOM tools. As such, the final iterations for usability testing were released for public consumption.

Following the completion of the English-language products, our team culturally adapted these tools for use in Pakistan. This project was funded by WCHRI [15]. Outputs and images of the Pakistani tools can be found on page 13 and on the ECHO KT website (www.echokt.ca). 
medRxiv preprint doi: https://doi.org/10.1101/2021.06.29.21259431; this version posted July 3, 2021. The copyright holder for this preprint (which was not certified by peer review) is the author/funder, who has granted medRxiv a license to display the preprint in perpetuity.

\section{Conclusions}

We developed and evaluated the usability of two innovative, arts-based, digital tools for parents with children with acute otitis media. Using comprehensive methods, our AOM tools were developed over the course of two years and involved several important steps: (1) synthesis of evidence from the literature; (2) collection of our own evidence through interviews with parents who have had children with AOM; (3) content outline development; (4) tool design and development; (5) several rounds of revisions and modifications with stakeholders and the study team, and (6) usability testing with our end-users, parents. High scores across all usability items for both tools suggest that using multi-method development processes can result in tools that are useful, relevant, understandable, and will be used by the intended audience.

Our tools are easily accessible and can be viewed across a broad range of devices, including desktop computers, mobile phones, and tablet devices. Providing a means for quick and convenient access ensures that parents can obtain information about how to manage their child's condition at the tip of their fingers. Such resources may not only help parents save time but may also alleviate the burden on the health system, such that it provides information for parents to make evidence-based informed decisions to manage their child's condition at home.

The tools can be found here: http://www.echokt.ca/tools/ear-infection/

Note: Our KT tools are assessed for alignment with current, best-available evidence every two years. If recommendations have changed, appropriate modifications are made to our tools to ensure that they are up-to-date [16]. 
medRxiv preprint doi: https://doi.org/10.1101/2021.06.29.21259431; this version posted July 3, 2021. The copyright holder for this preprint (which was not certified by peer review) is the author/funder, who has granted medRxiv a license to display the preprint in perpetuity. It is made available under a CC-BY-NC-ND 4.0 International license .

\section{Other Outputs from this Project}

\section{Research Papers}

Meherali, S., Hartling, L., Campbell, A., Featherstone, R., Scott, S.D. (2021). Parent information needs and experience regarding acute otitis media in children: A systematic review. Patient Education and Counseling, 104(3), 554-562.

https://doi.org/10.1016/j.pec.2020.09.013

Meherali, S., Campbell, A., Hartling, L., Scott, S.D. (2018) Understanding parents' experiences and information needs on pediatric acute otitis media: a qualitative study. Journal of Patient Experience, 6(1), 53-61. https://doi.org/10.1177/2374373518771362

\section{Presentations \& Research Conferences}

Campbell, A., Meherali, S., Hartling, L., \& Scott, S.D. The development and usability evaluation of an interactive infographic as a knowledge translation tool for pediatric acute otitis media. KT Canada Scientific Meeting. May 30, 2019. Winnipeg, MB.

Campbell, A., Le, A., Meherali, S., Fitzpatrick, E., Hartling, L., Scott, S.D. The development and usability evaluation of a whiteboard animation video for acute otitis media. Margaret Scott Wright Research and Innovation Day, Edmonton, AB. November 2, 2018.

Campbell, A., Le, A., Meherali, S., Fitzpatrick, E., Hartling, L., Scott, S.D. (Oral presentation) The development and usability evaluation of a whiteboard animation video for acute otitis media. 10th Annual Women and Children's Health Research Institute Research Day. Edmonton, AB. October 24, 2018.

Le, A., Campbell, A., Meherali, S., Fitzpatrick, E., Hartling, L., Scott, S.D. The development and usability evaluation of a whiteboard animation video for acute otitis media. Canadian Association of Paediatric Health Centres Research Day. Edmonton, AB. October 22, 2018.

Campbell, A., Meherali, S., Scott, S.D., Hartling, L. Understanding parents' experiences and information needs on pediatric acute otitis media to inform the development of a narrative arts-based KT tool. 10th Annual Dr. Olive Yonge Teaching \& Learning Day. University of Alberta. Edmonton, Alberta. March 29, 2018.

Meherali, S., Scott, S.D., \& Hartling, L. (Oral presentation) Parent information needs and experience regarding acute otitis media in children: A systematic review. CHLA/ABSC 2017 Annual Conference. Edmonton, Alberta. May 17-19, 2017. 


\section{Outputs from the Pakistan AOM Project}

\section{Research Papers}

Meherali, S., Scott, S.D., Hartling, L. (2020) Cultural adaptation of digital knowledge translation tools to improve child health outcomes in low-middle-income countries: A mixed-methods usability evaluation. JMIR Formative Research, 9(8), e19108. https://doi.org/10.2196/19108

\section{Presentations \& Research Conferences}

Meherali, S., Campbell, A., Hartling, L., \& Scott, S.D. Digital knowledge translation tools on otitis media for Canadian and Pakistani Parents. 10th Annual Dr. Olive Yonge Teaching \& Learning Day. University of Alberta. Edmonton, Alberta. March 29, 2018.

Meherali, S., Campbell, A., Hartling, L., \& Scott, S.D. Digital knowledge translation tools on otitis media for Canadian and Pakistani parents. University of Alberta, Postdoctoral Fellows Association Research Day. Edmonton, Alberta. November 02, 2017.

Meherali, S., Campbell, A., Hartling, L., \& Scott, S.D. Digital knowledge translation tools on otitis media for Canadian and Pakistani parents. CAPHC Annual Conference. Montreal, Quebec. October 22-24.

Meherali, S., Scott, S.D., \& Hartling, L. Digital knowledge translation tools on otitis media for Canadian and Pakistani parents. Summer Institute 2017 Conference. Edmonton, Alberta. June 25-27, 2017.

Meherali, S.M., Hartling, L., Buckreus, K., \& Scott, S.D. (2016). Digital knowledge translation tools on Otitis media for Canadian and Pakistani parents. Margret Scott Wright conference Edmonton, November 4-6 
medRxiv preprint doi: https://doi.org/10.1101/2021.06.29.21259431; this version posted July 3, 2021. The copyright holder for this preprint (which was not certified by peer review) is the author/funder, who has granted medRxiv a license to display the preprint in perpetuity. It is made available under a CC-BY-NC-ND 4.0 International license .

\section{References}

1. Boatright, C. (2015). Treatment Patterns for Pediatric Acute Otitis Media: A Gap in EvidenceBased Theory and Clinical Practice. Pediatric Nursing, 41(6), 271-276.

2. Le Saux, N., \& Robinson, J. L. (2016). Management of acute otitis media in children six months of age and older. Paediatr Child Health, 21(1), 39-50.

3. Teele, D. W., Klein, J. O., Rosner, B., \& Greater Boston Otitis Media Study, G. (1989). Epidemiology of Otitis Media during the First Seven Years of Life in Children in Greater Boston: A Prospective, Cohort Study. The Journal of Infectious Diseases, 160(1), 83-94.

4. Curran, J. F., Cornwall, H. L., Perenyei, M., \& Moorhouse, T. (2018). Acute otitis media. InnovAiT, 11(6), 305-312. https://doi.org/10.1177/1755738018766193

5. Meherali, S., Campbell, A., Hartling, L., \& Scott, S. Understanding Parents' Experiences and Information Needs on Pediatric Acute Otitis Media:A Qualitative Study. Journal of Patient Experience, $O(0), 2374373518771362$. https://doi.org/10.1177/2374373518771362

6. Hansen, M. P., Howlett, J., Del Mar, C., \& Hoffmann, T. C. (2015). Parents' beliefs and knowledge about the management of acute otitis media: a qualitative study [journal article]. BMC Family Practice, 16(1), 82. https://doi.org/10.1186/s12875-015-0297-7

7. Scott, S. D., Hartling, L., \& Klassen, T. P. (2009). The power of stories: using narratives to communicate evidence to consumers. Nursing for Women's Health, 13(2), 109-111. https://doi.org/10.1111/j.1751-486X.2009.01401.x

8. Charon, R. (2000). Literature and medicine: origins and destinies. Acad Med, 75(1), 23-27. https://doi.org/10.1097/00001888-200001000-00008

9. Charon, R. (2008). Narrative medicine: Honoring the stories of illness. Oxford University Press.

10. TRanslating Emergency Knowledge for Kids (TREKK). Acute Otitis Media - Bottom Line Recommendations. November 2016 - Version 1.0. Retrieved from: https://trekk.ca/resources?utf8=\%E2\%9C\%93\&tag_id=D010033\&external_resource_type=All

11. Hartling, L., Elliott, S.A., Buckreus, K., Leung, J., Scott, S.D. (2021). Development and evaluation of a parent advisory group to inform a research program for knowledge translation in child health. Res Involv Engagem, 7(38). https://doi.org/10.1186/s40900-021-00280-3

12. Hornbæk, K. (2006). Current practice in measuring usability: Challenges to usability studies andresearch. International journal of human-computer studies. 64(2), 79-102.

13. Carifio, J., \& Perla, R. (2008). Resolving the 50-year debate around using and misusing Likert scales. Blackwell Publishing, 42, 1150-1152.

14. Sullivan, G.M., \& Artino Jr., A.R. (2013). Analyzing and interpreting data from Likert-type scales. Journal of Graduate Medical Education, Editorial.

15. Scott, S.D., Hartling, L, \& Meherali, S. (2016). A digital knowledge translation tool for otitis media for Canadian and Pakistani parents. Women and Children's Health Research Institute Innovation grant $(\$ 50,000)$. 2016/07-2018/06.

16. Featherstone, R.M., Leggett, C., Knisley, L., Jabbour, M., Klassen, T.P., Scott, S.D., Van De Mosselaer, G., Hartling, L. (2018). Creation of an integrated knowledge translation process to improve pediatric emergency care in Canada. Health Commun, 33(8), 980-987. https://www.doi.org/ 10.1080/10410236.2017.1323538. 


\section{Appendices}

\section{Appendix A - Interview Guide}

Parents will be interviewed to understand their experience having a child with otitis media. Semi-structured interviews will be conducted with parents in order to get their "narrative" or experiences. The following questions will be used to guide these interviews. Being true to semi-structured interview techniques, interview questions will start broad and then move to the more specific.

1. Tell me about your experience having your child experience otitis media.

2. Tell me about your child that was ill. How old is your child? How was your child ill? Has your child previously had otitis media?

3. How did you feel during this experience?

4. What did you do to manage symptoms of otitis media? (any techniques you used, for example, giving Tylenol, talking with family/friends, etc.)

5. What strategies were put in place by health care professionals to help your child? (for example, giving/prescribing antibiotics). Did they ask you to do anything?

6. How did your child manage the experience? How did you feel about the outcome of this situation?

7. If presented with the same situation again, would you do anything differently? If so, please tell me. 
medRxiv preprint doi: https://doi.org/10.1101/2021.06.29.21259431; this version posted July 3, 2021. The copyright holder for this preprint (which was not certified by peer review) is the author/funder, who has granted medRxiv a license to display the preprint in perpetuity.

It is made available under a CC-BY-NC-ND 4.0 International license.

Appendix B - Video Images

\section{HOW TO MANAGE YOUR CHILD'S EAR INFECTION}

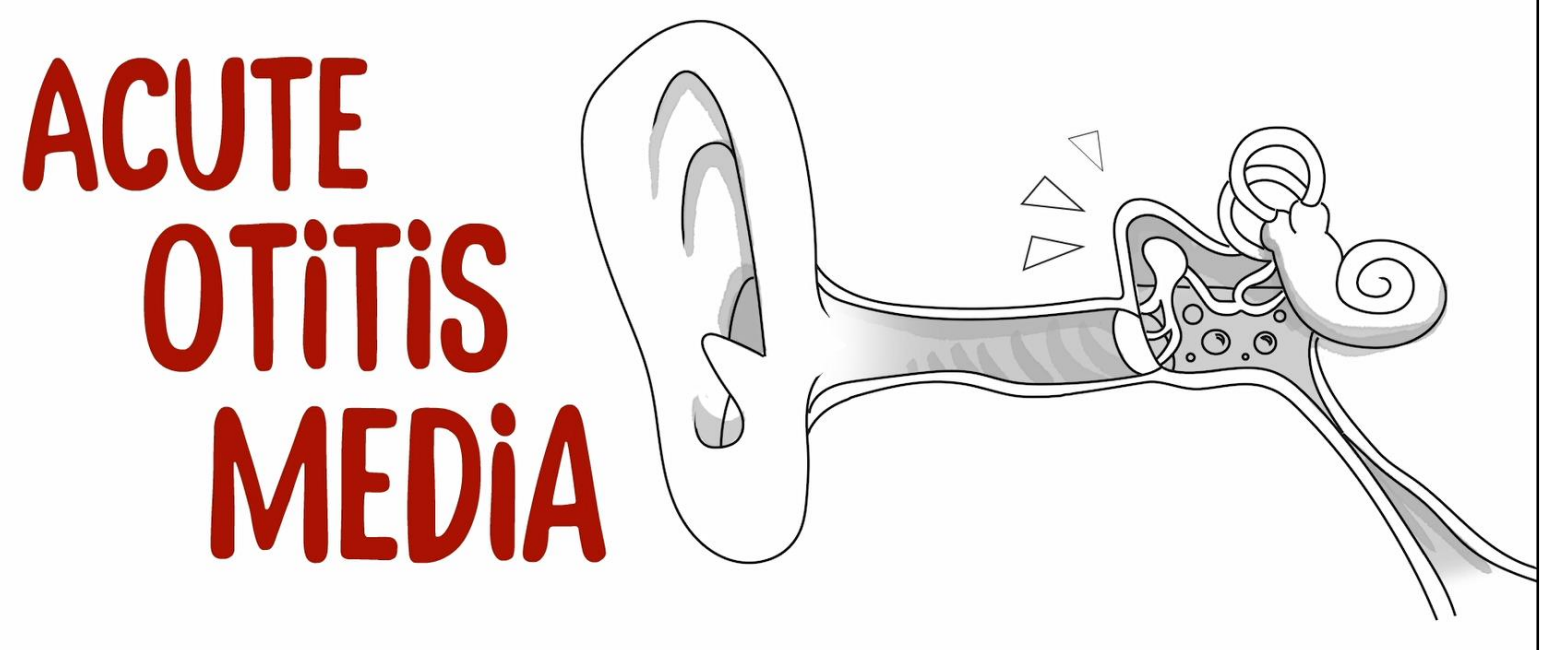




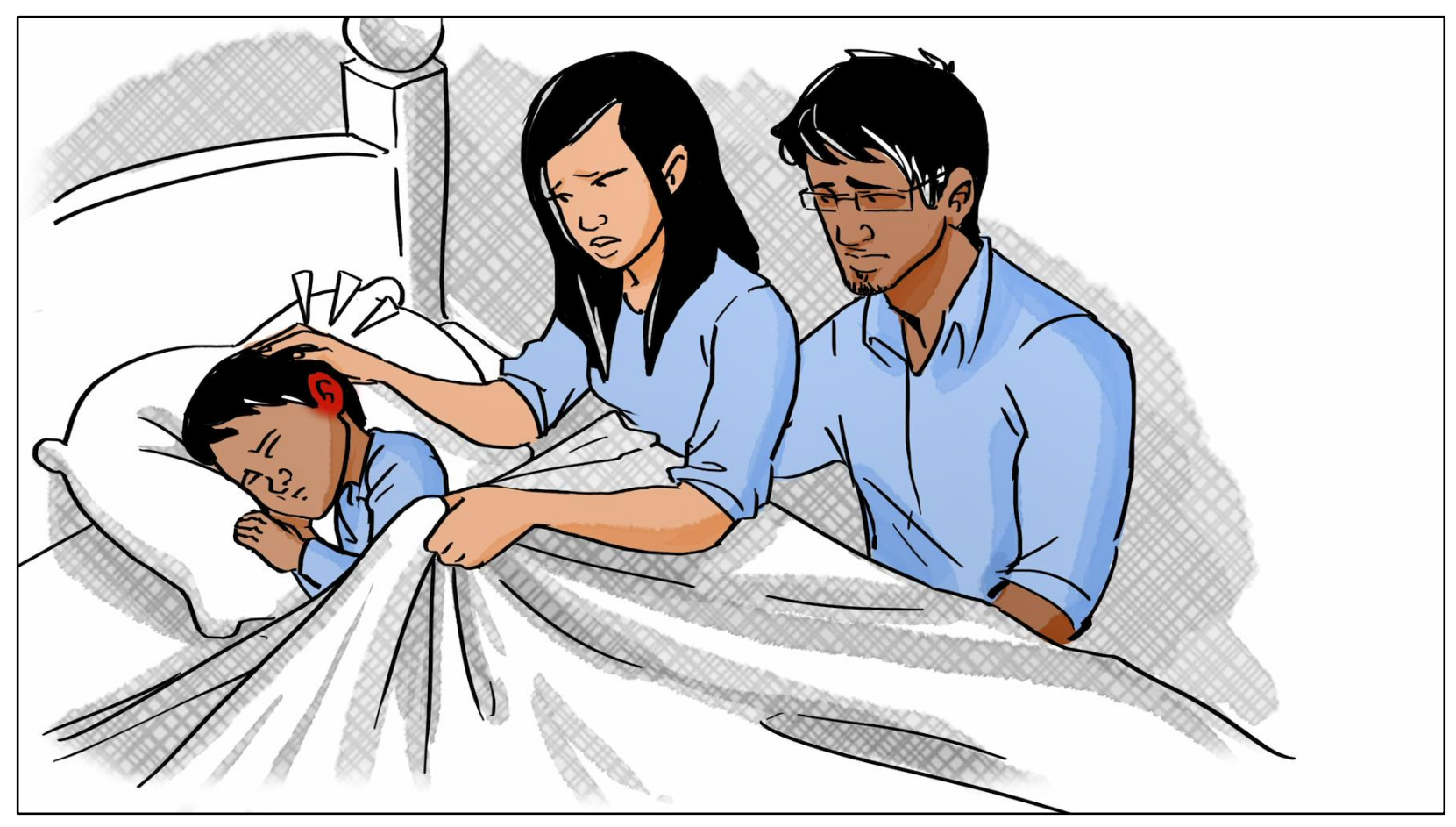

\section{EAR INFECTION SYMPTOMS}

mild fever $\left(<39^{\circ} \mathrm{C}\right.$ or $\left.<102.2^{\circ} \mathrm{F}\right)$

ear pain

cry or pull ear

difficult time sleeping or eating

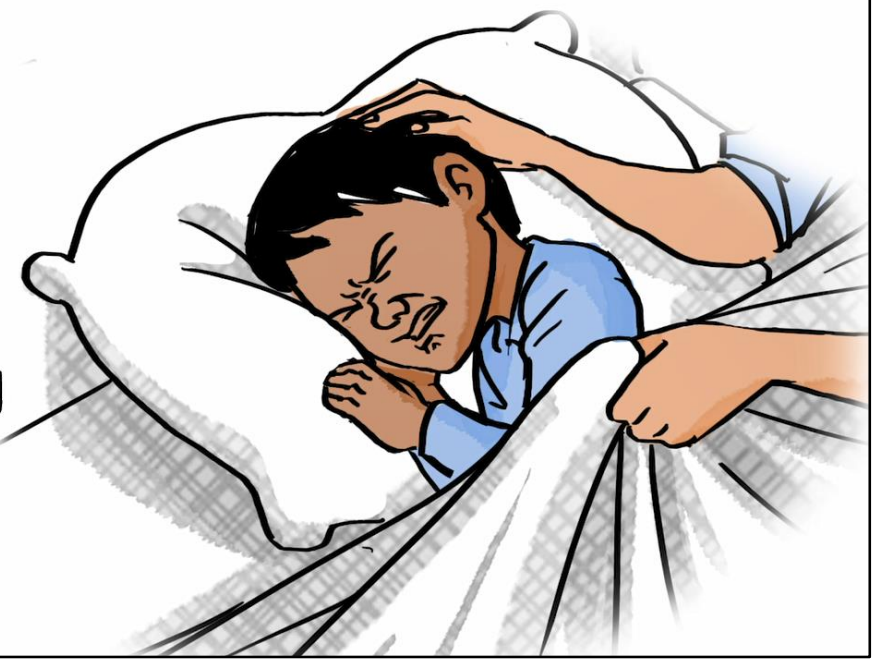




\section{NO NEED to RETURN to the DOCTOR if your CHIILD IMPROVES in the NEXT 48 HOURS}

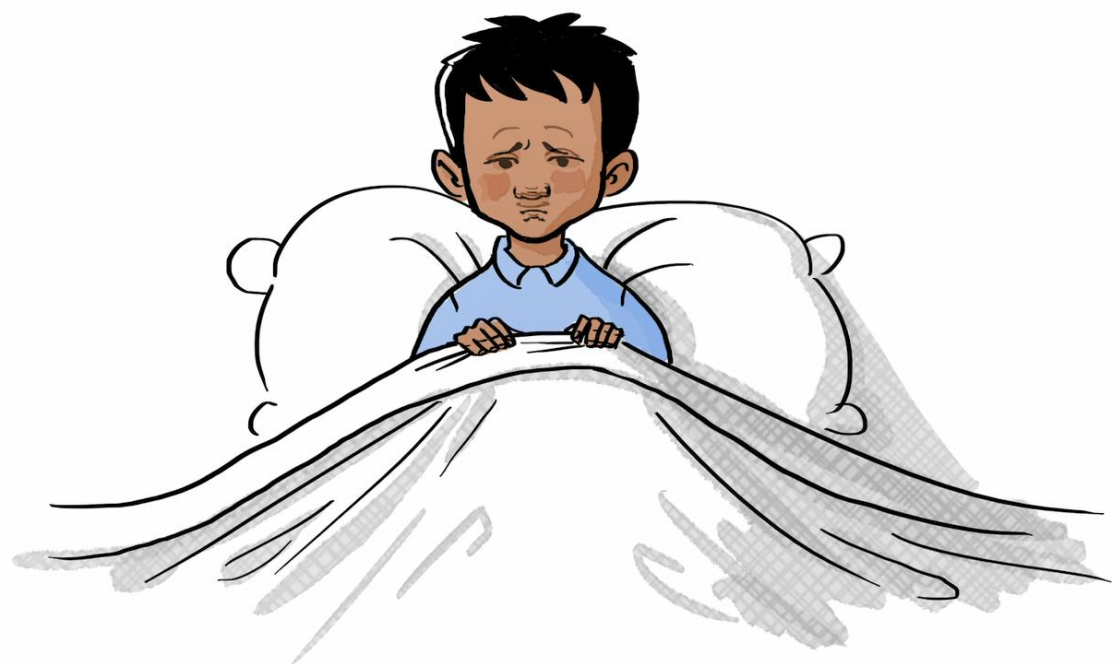

If The PAIN AND the FEVER CONTINUE FOR ANOTHER 48 HOURS

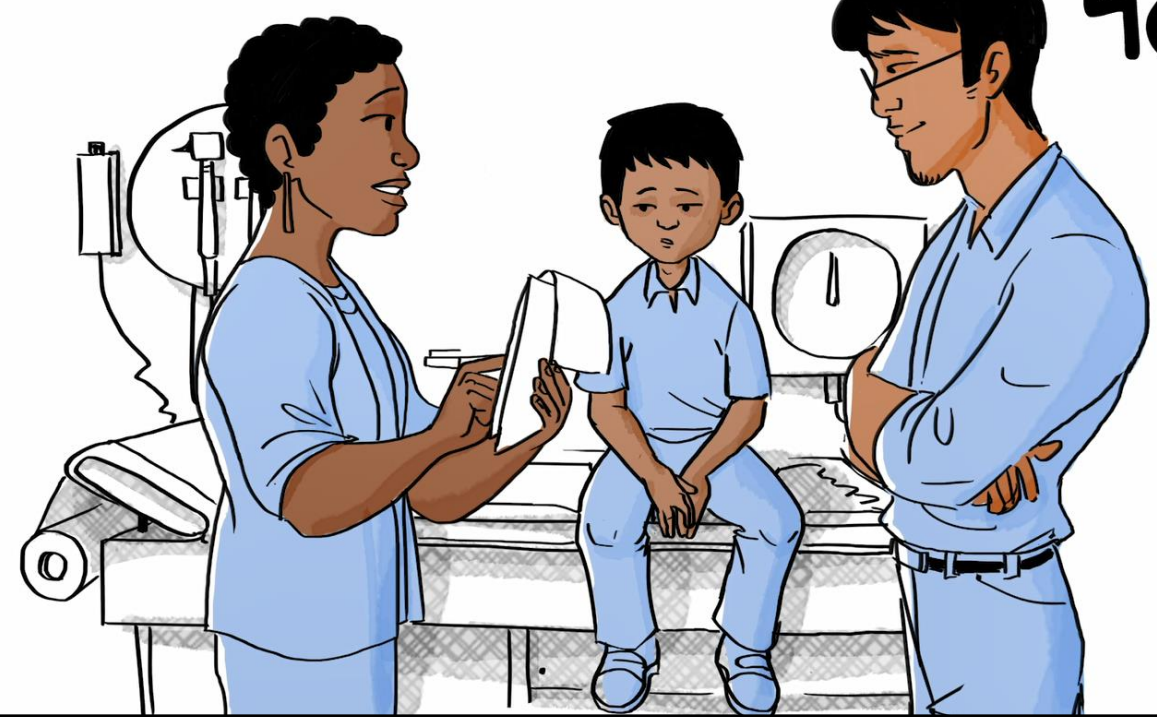

START THE ANTIBIOTICS RIGHT AWAY 
medRxiv preprint doi: https://doi.org/10.1101/2021.06.29.21259431; this version posted July 3, 2021. The copyright holder for this preprint (which was not certified by peer review) is the author/funder, who has granted medRxiv a license to display the preprint in perpetuity. It is made available under a CC-BY-NC-ND 4.0 International license .

\section{Appendix C - Infographic Images}

\section{Does Your Child Have Ear Pain?}

\section{If so, it might be an ear infection (also known as acute otitis media)}

scroll down for more

\section{Looking for}

\section{Signs my child may have an ear infection}

Your child does not need to have all of the signs to have an ear infection.

Your child may have an ear infection even if they don't have all of these signs.

Common Signs
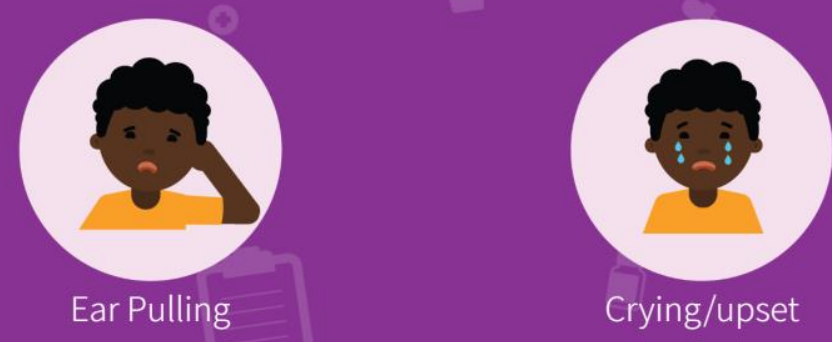
medRxiv preprint doi: https://doi.org/10.1101/2021.06.29.21259431; this version posted July 3, 2021. The copyright holder for this preprint (which was not certified by peer review) is the author/funder, who has granted medRxiv a license to display the preprint in perpetuity.

It is made available under a CC-BY-NC-ND 4.0 International license .

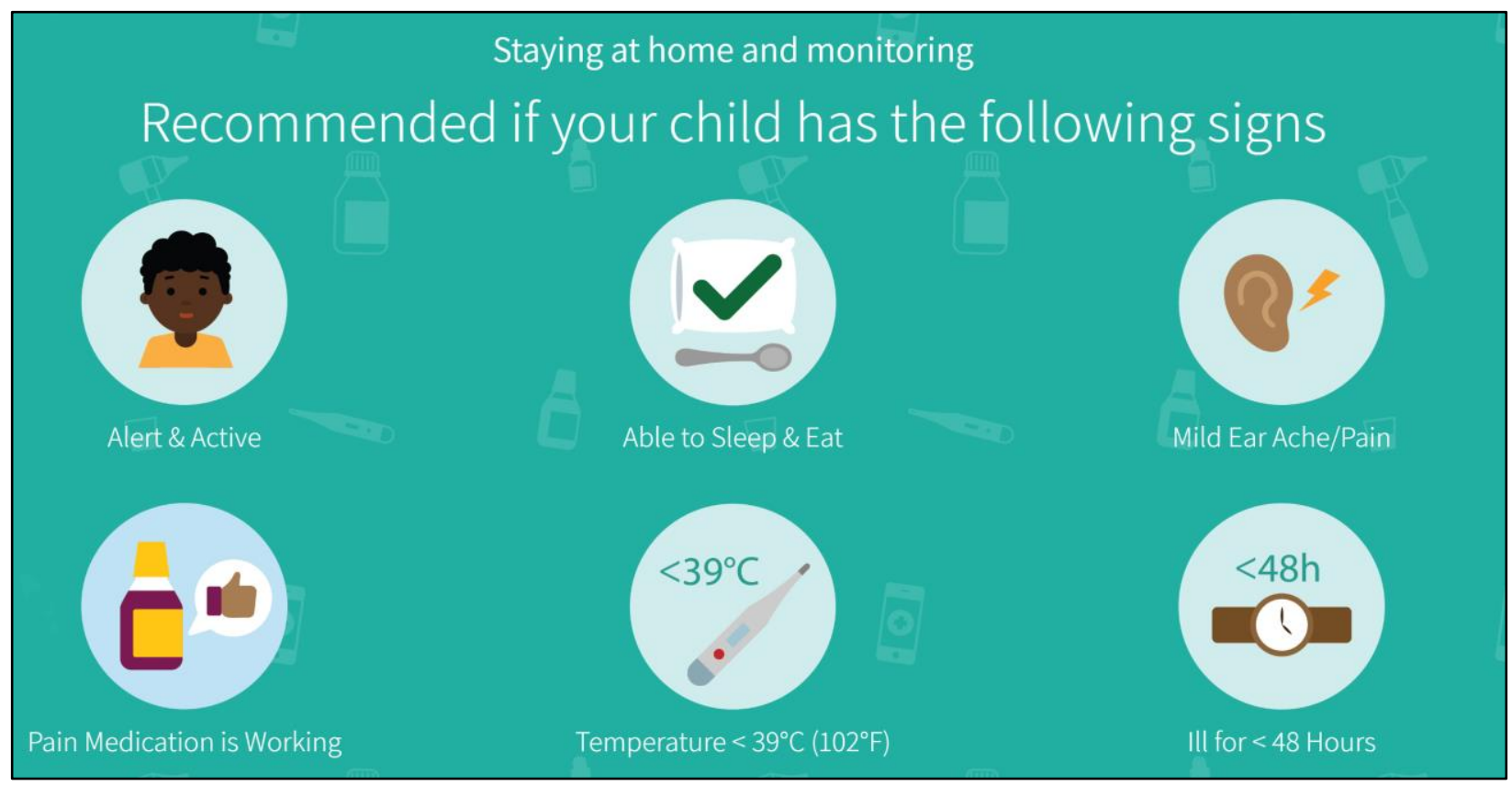

\section{Additional Resources}

\section{Click here to learn more!}

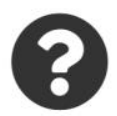

Questions? Comments?

\section{Contact Us}




\section{Appendix D - Usability Survey}

SECTION 1: Demographics

1) What is your gender?

$\square$ Male

$\square$ Female

3) What is your Age?

$\square$ Less than 20 years old

$\square$ 20-30 years

$\square 31-40$ years

$\square$ 41-50 years

$\square 51$ years and older

4) What is your Marital Status?

$\square$ Married

$\square$ Single

5) What is your gross annual household income?

$\square$ Less than $\$ 25,000$

$\square \$ 25,000-\$ 49,999$

$\square \$ 50,000-\$ 74,999$

$\square \$ 75,000-\$ 99,999$

$\square \$ 100,000-\$ 149,999$

$\square \$ 150,000$ and over

6) What is your highest level of education?

$\square$ Some high school

$\square$ High school diploma

$\square$ Some post-secondary

$\square$ Post-secondary certificate/diploma

$\square$ Post-secondary degree

$\square$ Graduate degree

$\square$ Other

7) How many children do you have?

8) How old are your children? 
medRxiv preprint doi: https://doi.org/10.1101/2021.06.29.21259431; this version posted July 3, 2021. The copyright holder for this preprint (which was not certified by peer review) is the author/funder, who has granted medRxiv a license to display the preprint in perpetuity.

It is made available under a CC-BY-NC-ND 4.0 International license .

SECTION 2: Assessment of attributes of the arts-based, digital tools *participant is randomized to view 1 of 2 digital tools then automatically directed to the survey

1. It is useful. [5-point Likert Scale]

2. It provides information that is relevant to me as a parent. [5-point Likert Scale]

3. It is simple to use. [5-point Likert Scale]

4. I can use it without written instructions or additional help. [5-point Likert Scale]

5. Its length is appropriate. [5-point Likert Scale]

6. It is aesthetically pleasing (i.e., images, colours, etc.). [5-point Likert Scale]

7. It helps me to make decisions about my child's health. [5-point Likert Scale]

8. I would use it in the future. [5-point Likert Scale]

9. I would recommend it to a friend. [5-point Likert Scale]

10. List the most negative aspects: [open text]

11. List the most positive aspects: [open text] 
medRxiv preprint doi: https://doi.org/10.1101/2021.06.29.21259431; this version posted July 3, 2021. The copyright holder for this preprint (which was not certified by peer review) is the author/funder, who has granted medRxiv a license to display the preprint in perpetuity.

It is made available under a CC-BY-NC-ND 4.0 International license .

\title{
Appendix E - Project Timeline
}

\section{Development Timeline}

\author{
Acute Otitis Media
}

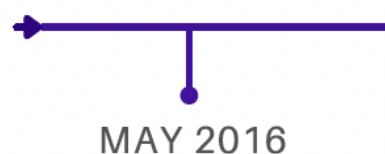

Qualitative Interviews

JULY 2016

Systematic Review

Conducted
NOVEMBER 2016

Video Script

Development

\section{FEBRUARY 2017}

Feedback Gathered from Health Care Professionals at

PERC*

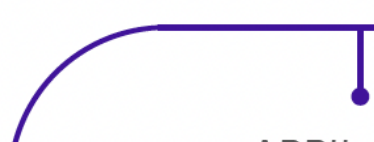

APRIL 2017

Interactive Infographic

(Pakistan) Development Begins

\section{MARCH 2017 \\ Video (Pakistan) \\ Development Begins}

FEBRUARY 2017

Video Development

Begins

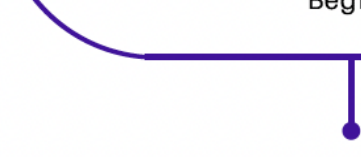

MAY 2017

Feedback Gathered from P-PAG^

JUNE 2017

Interactive Infographic (Pakistan) and Video Prototype Complete

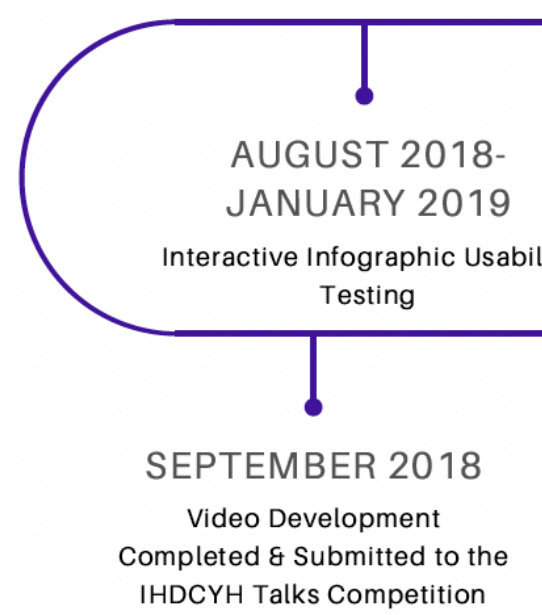

IHDCYH Talks Competition

\& Special Commendation

Received from IHDCYH Talks

Competition (\$750)

JULY 2018
Infographic Prototype

Complete

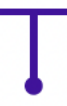

JUNE 2017 -

AUGUST 2017

Video Usability Testing

Video Usability Testing

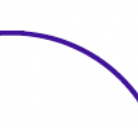

